\title{
Synthesis of bioactive materials for implants in the system $\mathrm{Ca}_{3}\left(\mathrm{PO}_{4}\right)_{2}-\mathrm{Ca}_{2} \mathrm{GeO}_{4}$
}

\author{
Elizaveta A. Mukhanova ${ }^{1,2, *}$, Vyacheslav G. Vetokhin ${ }^{1}$, Alexander A. Rybalkin ${ }^{1}$ \\ ${ }^{1}$ Southern Federal University, 344006 Rostov-on-Don Bolshaya Sadovaya str. 105/42, Russia \\ ${ }^{2}$ Don State Technical University, 344000 Rostov-on-Don pl. Gagarina 1, Russia
}

\begin{abstract}
Various modifications of Ge-substituted calcium phosphates were obtained using solid-phase synthesis, co-precipitation in solution, and combustion synthesis. Structural changes in the synthesis process are established using X-ray diffraction. The biological activity of the obtained samples in model fluids was estimated. It has been found that the synthesis method can lead to various structural modifications of calcium phosphate, which is a significant refinement to the phase diagram of the $\mathrm{Ca}_{3}\left(\mathrm{PO}_{4}\right)_{2}-$ $\mathrm{Ca}_{2} \mathrm{GeO}_{4}$ system described in the literature.
\end{abstract}

\section{Introduction}

Many calcium phosphates are used in implants or as a low release drug delivery systems [1-6]. The best known and widely used among them are hydroxyapatite $\mathrm{Ca}_{5}\left(\mathrm{PO}_{4}\right)_{3}(\mathrm{OH})$ and $\beta-\mathrm{Ca}_{3}\left(\mathrm{PO}_{4}\right)_{2}$ (whitlockite) [5,7-10]. The substitution of calcium and phosphorous allows obtaining materials with improved properties. For example, the addition of silicon to hydroxyapatite and $\beta$-tricalcium-phosphate materials is being widely studied, due to the well-known influence of silicon on bone formation [11,12]. Amount of silicon in hydroxyapatite depends on a synthetic route while silico-carnotite has the constant concentration of $\mathrm{Si}^{4+}$ [13].

$\mathrm{Ge}^{4+}$ has some similarity to $\mathrm{Si}^{4+}$-containing materials. And its compounds have some special properties. For example, the oral administration of Ge-132 increases interferon activity and exhibits antitumour activity against Ehrlich ascites tumours in mice. [14-17].

$\mathrm{Ca}_{5}\left(\mathrm{PO}_{4}\right)_{2} \mathrm{GeO}_{4}$ with silico-carnotite structure was described in [18]. The authors obtained carnotite in system $\mathrm{Ca}_{3}\left(\mathrm{PO}_{4}\right)_{2}-\mathrm{Ca}_{2} \mathrm{GeO}_{4}$ while cooling melt different composition from $1500{ }^{\circ} \mathrm{C}$. The development of synthesis at lower temperatures is important and became the aim of our investigation. We analyzed opportunity to prepare calcium germinatephosphate with the specific structure using solid-state reaction, combustion and coprecipitation techniques.

\footnotetext{
* Corresponding author: kand@sfedu.ru
} 


\section{Materials and methods of research}

\subsection{Preparation of Ge-substituted calcium phosphate}

Ge-substituted calcium phosphates $\mathrm{Ca}_{5}\left(\mathrm{PO}_{4}\right)_{2} \mathrm{GeO}_{4}$ were obtained by three different methods. In solid-state synthesis, we used as the initial reactants $\mathrm{CaCO}_{3}, \mathrm{GeO}_{2}$ and $\left(\mathrm{NH}_{4}\right)_{2} \mathrm{HPO}_{4}$. The mixtures were prepared in an agate mortar, pressed into pellets and heated at $500{ }^{\circ} \mathrm{C}$ for $2 \mathrm{~h}$ to mild decompose of $\left(\mathrm{NH}_{4}\right)_{2} \mathrm{HPO}_{4}$ and activate $\mathrm{CaCO}_{3}$ during it phase transition at $\mathrm{T}=590^{\circ} \mathrm{C}$ and then heated at 900,1000 and $1100{ }^{\circ} \mathrm{C}$ during 2 hours each. The samples were repeatedly reground during synthesis. The samples were quenched in air.

For co-precipitation in the solution we used as the initial reactants $\mathrm{GeO}_{2}, \mathrm{Ca}(\mathrm{OH})_{2}$ and $2.1 \mathrm{M} \mathrm{H}_{3} \mathrm{PO}_{4}$. The first step was to prepare a soluble form of ammonium germanate. $\mathrm{GeO}_{2}$ was stirred under an ammonium hydroxide solution for 24 hours. The second step was to prepare the calcium phosphate solution by mixing $0.6 \mathrm{M}$ solution of $\mathrm{Ca}(\mathrm{OH})_{2}$ and $2.1 \mathrm{M}$ $\mathrm{H}_{3} \mathrm{PO}_{4}$ at $\mathrm{pH} \sim 10-11$. This solution was added to the $\left(\mathrm{NH}_{4}\right)_{2} \mathrm{Ge}_{5} \mathrm{O}_{11}$ solution stirring constantly for 24 hours. The obtained precipitation was thermally treated at $1100^{\circ} \mathrm{C}$ for 2 hours.

For combustion method, we used $\mathrm{GeO}_{2}, \mathrm{CaCO}_{3}, \mathrm{H}_{3} \mathrm{PO}_{4}$, and $\mathrm{C}_{2} \mathrm{H}_{5} \mathrm{OH}$. We prepared $\left(\mathrm{NH}_{4}\right)_{2} \mathrm{Ge}_{5} \mathrm{O}_{11}$ solution as described previously. $\mathrm{CaCO}_{3}$ was dissolved in $\mathrm{HNO}_{3}$. Three solutions were mixed together. We added citric acid and ethylene glycol in ethanol to form a mixed solution, with the $\mathrm{Ge}^{4+}$ and a $\mathrm{Ca}^{2+}$-to-citric acid molar ratio of $1: 2$ and the ethylene glycol-to citric acid molar ratio of 1.2:1 [19]. During these procedures, the solution was continuously stirred using a magnetic agitator for a few days. Then, the stabilized sol was poured into a glass beaker and stirred constantly to transform a dried gel at $80{ }^{\circ} \mathrm{C}$. The beaker was transferred to a muffle furnace preheated at $900{ }^{\circ} \mathrm{C}$, and by heating, the dried gel simultaneously burnt in a self-propagating combustion manner until all the gels were burnt out completely to form a white powder. After burnt out at $900{ }^{\circ} \mathrm{C}$ for $2 \mathrm{~h}$, the specimens were sintered at different temperatures 1000 and $1100{ }^{\circ} \mathrm{C}$ for $2 \mathrm{~h}$ in the air.

\subsection{Characterization Techniques}

The phases presented in the samples were identified by X-ray powder diffraction. The data were collected with an ARL X'TRA diffractometer in Ni-filtered $\mathrm{CuK}_{\alpha}$-radiation.

\section{Results and discussion}

The XRD pattern of the sample prepared by a solid-state reaction is shown on Fig. 1. The main phase has a structure of $\beta-\mathrm{Ca}_{3}\left(\mathrm{PO}_{4}\right)_{2}$ whitlockite. The samples prepared by coprecipitation and combustion techniques are shown in Fig. 2. The main phase in both cases has a structure of hydroxyapatite. Sample from co-precipitation reaction has higher crystallinity.

To discuss the effect of the synthetic route on a preferable structure we need to compare structure to each other. Fig. 3 a-c presents all structure types: whitlockite (Fig. 4a), hydroxyapatite $(4 \mathrm{~b})$ and silico-carnotite $(4 \mathrm{c})$. All structures have similar densities. $\mathrm{PO}_{4}$ tetrahedra are isolated in all of them but coordination number of calcium ion is different. Calcium in silico-carnotite has 7 nearest oxygen, in hydroxyapatite 7 and 9 neighbors and in $\beta-\mathrm{Ca}_{3}\left(\mathrm{PO}_{4}\right)_{4}-10$ and 12 oxygens. And based on this fact the phase diagram of $\mathrm{Ca}_{3}\left(\mathrm{PO}_{4}\right)_{2}-\mathrm{Ca}_{2} \mathrm{GeO}_{4}$ need to refine. All samples have the identical composition and the main factor which affect on the sustainability of structure type is a synthetic route. The 
temperature above $1500{ }^{\circ} \mathrm{C}$ is preferable to silicocarnotite type. The lower temperatures lead to whitlockite (in solid state) or hydroxyapatite (in solutions). One more factor which influences on hydroxyapatite formation is $\mathrm{pH}$ - all reaction in solution took place at $\mathrm{pH}=10-11$, while other phosphates form at another $\mathrm{pH}$. And whitlockite looks like more stable phase under 1200 while except additional conditions. In all structures, this material can have bioactivity as structure analogs and considering of know application of germanium compounds in medicine.

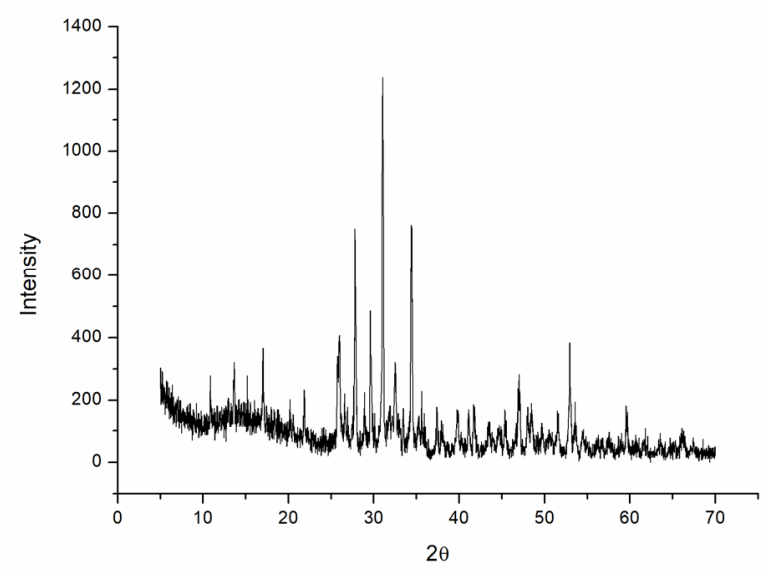

Fig. 1. XRD patterns of $\mathrm{Ca}_{5}\left(\mathrm{PO}_{4}\right)_{2} \mathrm{GeO}_{4}$ obtained by solid-state reaction.

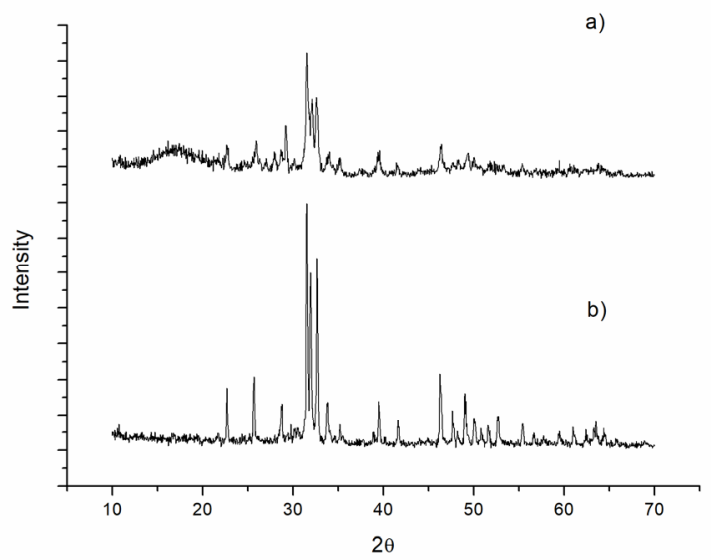

Fig. 2. XRD patterns of $\mathrm{Ca}_{5}\left(\mathrm{PO}_{4}\right)_{2} \mathrm{GeO}_{4}$ obtained by combustion method (a) and co-precipitation method (b).

\section{Conclusion}

We suggested that only synthesis at temperatures above $1200{ }^{\circ} \mathrm{C}$ led to a silico-carnotite structure. Under this condition despite on well-known phase diagram whitlockite or hydroxyapatite structure became preferable. This fact supplements well-known phase diagram $\mathrm{Ca}_{3}\left(\mathrm{PO}_{4}\right)_{2}-\mathrm{Ca}_{2} \mathrm{GeO}_{4}$ system. In our further studies, we will calculate the enthalpies of reaction and formation of different structures using atomistic modeling and CALPHAD methods. 


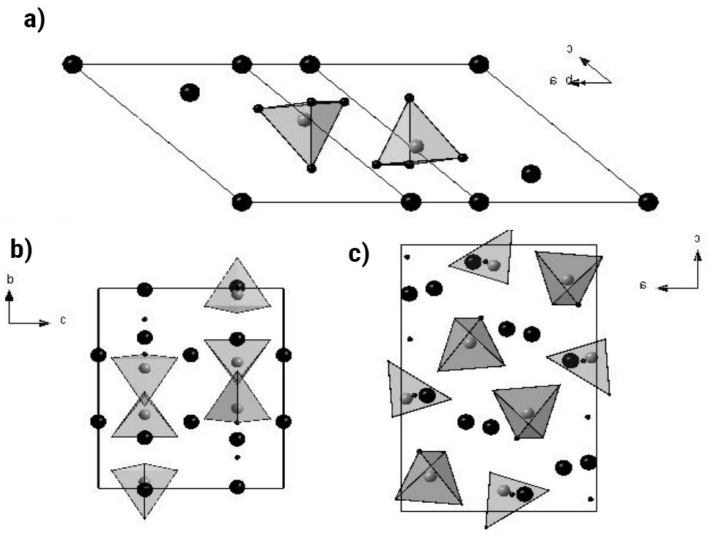

Fig. 3. Crystal structures of calcium phosphates: a) whitlockite $\beta-\mathrm{Ca}_{3}\left(\mathrm{PO}_{4}\right)_{2}$; b) hydroxyapatite $\left.\mathrm{Ca} 5\left(\mathrm{PO}_{4}\right)_{3} \mathrm{OH} ; \mathrm{c}\right)$ silico-carnotite $\mathrm{Ca}_{5}\left(\mathrm{PO}_{4}\right)_{2} \mathrm{SiO}_{4}$

This research was supported by grant of the Government of Russian Federation no. 14.Z50.31.0046.

\section{References}

1. J.H. Chung, Y.K. Kim, K.H. Kim, T.Y. Kwon, S.Z. Vaezmomeni, M. Samiei, M. Aghazadeh, S. Davaran, M. Mahkam, G. Asadi, A. Akbarzadeh Artif. Cells, Nanomedicine Biotechnol, 44, 277 (2016)

2. S. V Dorozhkin, Biomaterials, 31, 1465 (2010)

3. I.V. Antoniac, Springer International Publishing, Cham (2016)

4. B. Vernon, Woodhead Publishing Limited (2011)

5. R.T. Tran, D. Gyawali, P. Nair, J. Yang, A Handb. Appl. Biopolym. Technol. Synth. Degrad. Appl., 419 (2011)

6. L.B. Sukhodub, G.O. Yanovska, V.M. V.M., O.O. Martynyuk, L.F. Sukhodub J. NanoElectron. Phys. 8, 01032-1 (2016)

7. M. Laurenti, A. Al Subaie, M.-N. Abdallah, A.R.G. Cortes, J.L. Ackerman, H. Vali, K. Basu, Y.L. Zhang, M. Murshed, S. Strandman, J. Zhu, N. Makhoul, J.E. Barralet, F. Tamimi Nano Lett. (2016)

8. N. V. Bulina, M. V. Chaikina, K.B. Gerasimov, A. V. Ishchenko, D. V. Dudina, Mater. Lett. 164, 255 (2016)

9. C. Gao, Y. Deng, P. Feng, Z. Mao, P. Li, B. Yang, J. Deng, Y. Cao, C. Shuai, S. Peng, Int. J. Mol. Sci. 15, 4714 (2014)

10. A.C. Tas, J. Am. Ceram. Soc. 99, 1200 (2016)

11. Y. Li, C.P. Ooi, C. Philip Hong Ning, K. Aik Khor, Int. J. Appl. Ceram. Technol., 6, $501(2009)$

12. A.A. Zadpoor, Mater. Sci. Eng., 35, 134 (2014)

13. V. Hristov, L. Radev, B. Samuneva, G. Apostolov, Open Chem., 7, 702 (2009)

14. L.S. Keith, O.M. Faroon, N. Maples-Reynolds, B.A. Fowler, Handb. Toxicol. Met., Fourth Edi, Elsevier, 799, (2015)

15. C.D. Seaborn, F.H. Nielsen, Biol. Trace Elem. Res., 42, 151 (1994)

16. M. Dermience, G. Lognay, F. Mathieu, P. Goyens, J. Trace Elem. Med. Biol. 32, 86 (2015) 
17. K. Ozeki, Y. Fukui, H. Aoki, Biomed. Mater. Eng., 16, 33, (2006)

18. R. Martin, P.W. Brown, J. Am. Ceram. Soc 75, 1 (1992)

19. L.N. Mishenina, L.A. Selyunina, T.M. Botvina, Key Eng. Mater., 670, 95 (2015) 